\title{
Theorising about the Reasons for Which Professors Innovate in a University Strongly Committed to Research
}

\author{
Anne M. Walder (Corresponding author) \\ University of California, Los Angeles \\ Moore Hall, Westwood, Los Angeles, CA, United States
}

Tel: 1-41-78-724-11-25 E-mail: anne@walderpublications.ch

\author{
Received: July 23, 2014 Accepted: August 13, 2014 Published: September 12, 2014 \\ doi:10.5296/ire.v2i2.6303 URL: http://dx.doi.org/10.5296/ire.v2i2.6303
}

\begin{abstract}
Universities are torn these days between teaching and research, particularly within research universities, leading me to probe the major reasons that motivate professors to develop innovative pedagogical projects within universities that are strongly committed to research. Thirty-two semi-structured interviews with professors at the University of Montreal, all of whom are widely known to their peers, enabled us to theorise seven action plans and three significant stages concerning the reasons for which professors innovate. In other words, the primary reasons which motivate professors in universities strongly committed to research to develop pedagogically innovative projects may be categorised into seven action plans, 1) Captivating, 2) Supporting, 3) Problem-solving, 4) Improving, 5) Re-adapting, 6) Communicating and 7) Creating, and can be theorised in three major phases, 1). Desire to establish a relationship of trust, 2). Intentionality to change and 3). Integration of the desire to change within human relationships. Thus, it is a question of the desire to establish a relationship of trust with the intention of captivating and supporting students, an intentionality to change in order to provide a solution and improvement, and about the integration of the desire to change within human relationships, with the aim of re-adapting through communication and creation.
\end{abstract}

Keywords: Reasons for innovating, motivation, higher education

\section{Universities Today: Between Teaching and Research, a Dyad or a Dichotomy?}

The emergence of the institutionalisation of university research during the nineteenth century still produces lively controversy about the nature of the link between teaching and research. 
The different standpoints on this topic inflame differences of opinion torn between the liberal university model (Newman, 1889, part I.) and the scientific educational one (Von Humboldt, 1809, 1810; Jaspers, 1923).

The vocation of teaching within the context of universities, which focus on research, is a current problem leading to an inequality of investment between teaching and research (Gingras, 2003) and pressure from public policies, which insist that universities must innovate and be of institutional economic value in addition to their teaching and research. In other words, policies assert that the teaching mission of universities is not a priority and turn universities into "academic industrial centres" (Press \& Washburn, 2000).

Teaching duties and research duties both have their place within universities. If there is any controversy, then it is really about the respective emphasis given to one or the other (Gingras, 2003). It should be noted that the question of the link between teaching and research is a recurrent one and about which there is no consensus of opinion among authors. There are some who believe that teaching and research within universities are complementary, whereas others hold that they are opposed to each other. Consequently, is this really a dyadic or dichotomous relationship? I am going to try to understand the source of this connection.

History reveals that universities were not places for both teaching and research until the beginning of the nineteenth century whereas from the seventeenth to the nineteenth centuries, it was academics who were researchers and the professors who were teachers. The position of the "researcher-professor" first appeared in 1810 at the University of Berlin thanks to Von Humboldt, which gave rise to the overall concept of the unification of teaching, research, and study. However, even though this vision of the university focusing on research then spread to England, to the United States, and to other places in the world, the connection between teaching and research has nonetheless remained a problematic one (Hattie \& Marsh, 1996). In fact, Kogan (2004) reminds us that the researcher-professor has not always been practised everywhere; for example, in central and eastern Europe, where France and Norway grant special status to powerful institutes or scientific academies that are independent of universities.

Using educational models, I can discern differing understandings of the teaching role as opposed to the research role at universities. I shall start off with two authors (Condorcet, 1791; Newman, 1889) who distinguish research and teaching in precise terms and who believe that "the skill of teaching is not the same as someone who contributes to scientific progress" (Condorcet, 1994, p. 167) or that discovery and teaching are distinct roles (Newman, 1889, Part I). Condorcet (ibid.) categorically maintains that university academics must absolutely not be involved in teaching or set up a teaching body as it would have the consequence to weaken the scientist.

Newman (1889) adds that teaching and carrying out research involve quite different skills that rarely co-exist in the same person and he considers teaching and research as habitus that are opposites. He believes that teachers who transmit their accumulated knowledge cease to renew it and that the researcher's best friend in the quest for truth is solitude and silence. 
Let us now tackle a model which does not separate the teaching from the research role. The vision of the scientific education model confirms, in principle, the theory that there is no conflict between teaching and research. In this model for sciences, undertaking research and teaching are actions that are governed by identical principles in which the development of the scientific attitude remains crucial. Von Humboldt $(1809,1810)$ rejects the opposition between learned societies and universities and believes that learning is more dynamic in a university in which knowledge is continuously "taken up and rekindled" by a large number of keen young research students. Von Humboldt (ibid.) aims to build an organisational structure of research or theory and teaching or practice. According to him, university teaching assists study. The observation that there are individuals in every large university who teach little or not at all and who, by themselves, pursue their research enables him to maintain that a restructuring of universities can transfer the role of scientific development to universities and consequently demystify and desert learned societies.

From a pragmatic perspective, universities have to follow the utilitarian demands of society in some way in order to be at its service. Knowledge is, and must be, "practical", bringing something new and contributing to progress. The concept of the university professional school endowed with a specific field leads to a vision in which teaching does not develop outside of the real world and independent to current happenings. According to Whitehead (1929), knowledge is confronted with its constraints and difficulties. Lessard and Tardif (1998) highlight that this vision subjects universities to a utilitarian vision and that "in such a case, professional training will not be afraid to be well-established on university campuses" (p.18).

From the first part of this review of relevant literature, I can state that universities focused on research, treating teaching and research as two dyadic roles, fall victim to the problem of teaching. I will now explore the different aspects of this. Having benefited from a period of growth in university teaching and research from 1945 to 1980, As Gringras (2003), I am now paradoxically experiencing a significant decrease in public investment in higher education. Let us note, however, the efforts of Canada which offers, despite everything, unprecedented access to universities during this period and has established high-quality education supported by strong financial support by the federal government (Canada Foundation for Innovation, 2013). However, the crisis has also affected Canada from 1996, with a reduction of seven billion dollars in financial aid for teaching. This substantial decrease in state subsidies has led to a new order in the university dynamic. In fact, this loss of resources has resulted in the greater prominence of private funding, particularly from the industrial sector. These budget cuts have several consequences. They result in an imbalance in the ratio of "professors", with $3 \%$ fewer full-time ones, and "students", with 26\% more (Turk, 2005), but above all, they encourage universities focusing on research and dependent on funding to adopt a business management model which runs counter to the principles of the university system (Baillargeon, 2011). The collaboration between university research and industry, particularly in the fields of biomedical and chemical sciences, enables the universities in question both to have access to very costly equipment and to reap quick economic rewards for research that is produced (Gingras, 2003). The appearance of university research centres, grouping researchers around 
a given scientific topic as opposed to the university tradition which groups researchers according to their discipline, is developing with the objective of facilitating links between universities and business. This phenomenon is increasing and enables research that is conducted, to be more openly affirmed.

The topics that I have dealt with above confirm the existence of a significant imbalance between teaching and research in the majority of universities focusing on research. At the University of Montreal, a dilemma can be seen between professors who value teaching and risk being accused of being deficient in their research and those who are dedicating themselves more to research and for which they are receiving criticism because they do not teach as much as others.

Many attempts at extolling the complementarity of teaching and research have punctuated the history of universities in Canada. Indeed, the Association of Universities and Colleges of Canada (AUCC) $(2003,2006)$ explains that research and university teaching both carry equal weight for the country's future and highlights the importance of university education for individuals and for the social, economic, and cultural development of Canadian society. It also extols recognition of the right of learners to receive high-quality university teaching.

Two dichotomous theories grew out of the lively debates of the 1990s, which are simply compatibility on the one hand and incompatibility on the other (Clark, 1997). Right away, I note that the theory according to which teaching and research together constitute the heart of university life is hotly disputed (Henkel, 2004). Indeed, the literature allows us to note that these questions come from the key players of higher-education and science policy, as well as from sociologists who analyse the internal and external forces which separate these activities. Initial research carried out within Australian universities shows that there is statistically no significant correlation between university academics' performance in the field of research and in the field of teaching (Ramsden \& Moses, 1992). Secondly, a meta-analysis gathering together several explanatory models of the relationship between teaching and research from fifty-eight empirical studies adds that no statistically significant correlation between the quality of a teacher and that of a researcher has been detected (Hattie \& March, 1996). This conclusion is consolidated by other empirical research, for example that of Lindsay et al. (2002). I note that the matter is nuanced by a qualitative study, carried out with the help of interviews, which underscores the fact that professors believe that their research work influences their teaching and that their teaching duties have a positive impact on their research (Smeby, 1998). Furthermore, they believe that research is more important to teaching than the reverse. Finally, I note the relevant opinion held by Barnett (2003) who questions the strategy consisting of connecting two activities which have so many ideological differences.

Even though controversies and tensions between teaching and research have painted a negative picture of universities focusing on research, some authors see a "significant civilisational change" (Baillargeon, 2011, p. 10) or even a "second academic revolution" (Etzkowitz, 2001) transforming the role of universities within society. This business revolution leads to a new understanding of both teaching and research, confronted with 
unprecedented demands justified by market imperatives. Moreover, it becomes difficult to define what is meant by the term "research"'. According to De Jonghe (2005, p. 70), this term: "often includes different kinds of work". The author also notes that: "the emphasis is now more on acquiring rather than teaching knowledge" and describes how research is subject to criticism, because society's training needs are neglected.

Universities these days are managed like companies (Baillargeon, 2011). Research directors spend their time trying to obtain funding and supervising students and post-doctoral researchers to the detriment of their research (Etzkowitz, 2003). Gingras (2003) anticipates the potential risks of this dynamic in explaining that the researcher, already more easily caught up in this spiral when he or she deals with objects that are socially and intellectually further away, has the tendency to confuse desire and reality by omitting accuracy. Epistemological vigilance is indispensable when public policy mandates the requirement to innovate and be of economic value (Gringas, 2003). As for Baillargeon (2011), he is concerned about preserving the "life of the mind" (p. 30) at universities where research topics are set because they are funded and no longer because they are of research interest. No matter what the official line might say about attempting to draw teaching and research activities together, a review of publications highlights an increase in the distinction between research and teaching in Canada. According to the business concept, universities acknowledge research to be an activity which generates revenue and enhances reputation. Universities that are suffering from decreases in funding pressure professors to share their time between teaching, research, community service and university activities. Overwhelmed, they must make choices and sacrifice some tasks in order to safeguard the quality of their work.

I note a validation of research which is reflected by all of the investment and pressure put to bear on professors to carry out research and produce publications. The journal Tendances in the university community (AUCC, 2007), ranks Canada in thirteenth place among thirty member countries of the OECD with respect to research and development expenses. I can observe widespread enthusiasm there where Australia and Great Britain are committed to ensuring significant long-term funding within the context of their research strategy and the American federal government is launching a programme doubling its investment in basic research.

To return to Quebec universities, work carried out by Bertrand et al. (1997) demonstrates that the intensification and restructuring of research within universities ensures that teaching comes second in importance among all academic duties. These observations align with those of Bertrand and Foucher (2003) who hold that research specialisation already proves to be, and will become a necessity within the next few years. Nonetheless, a balance is sought through teaching provided with a wider object, in particular to avoid over-specialised teaching, notably with respect to undergraduate studies.

\section{Research Objective and Question}

The current status of scientific knowledge does not allow us to state categorically that teaching and research do not posses any inextricably connected relationship, but points, however, to a relationship that is dichotomous in nature. By doing so, it seems obvious to us 
that more value is given to research rather than teaching, and this is particularly the case in universities focusing on research. I note that the scientific-education model does not cover the characteristics of modern universities, and exacerbates the imbalance between teaching and research. While I believe it is crucial to balance teaching and research in a dynamic way with a view to establishing an effective structure that avoids any negative impact on students, I can observe that, despite the fact that teaching and research are the two pillars of higher education with equal importance, pre-eminence is given to research to the detriment of education.

Our research objective targets the reasons that motivate some professors to innovate within the context of pre-eminence given to research. Consequently, I explore the following research question: What are the primary reasons for which professors at universities strongly committed to research develop innovative pedagogical projects?

\section{What Do We Know about the Reasons for Innovating?}

Hannan and Silver (2000) have made a broad contribution to providing new knowledge about pedagogical innovation in higher education. From 1997 to 1999, they conducted a two phases qualitative research on two-hundred and twenty-one professors working in fifteen universities in England and were particularly interested in institutional culture and in the innovators. The first phase focused on the experience of the pedagogical innovators, that is to say professors who were involved in introducing teaching and learning methods that were new to their situation, within universities in which this innovation had clearly been integrated. The second involved detailed case studies within certain universities in order to assess the impact of the structure, process, and institutional culture in a general way as well as within the context of innovation.

The results of the research of Hannan, English, \& Silver (1999) envision seven reasons for innovating. These are the necessity relating to improving student learning, adapting to the new profile of students, satisfying the requirements of accreditation bodies, setting up internal restructuring or changes in the curriculum, inspiring general motivation, providing a source of inspiration and encouragement, and the fact that they consider themselves to be natural innovators.

I note that the student factor appears to be a variable which influences or determines the necessity of pedagogical innovation. Indeed, the work of Hannan et al. (1999) specifies that the primary reasons that inspire lectures to innovate are to put student learning to the test or changes in students. Béchard (2000) states that change in students is one of the reasons which inspires professors (31/103 respondents) to use pedagogical innovation in their teaching.

\section{Methodology}

For collecting our data, I carried out semi-directed interviews with 32 assistant, associate or full professors, all recipients of teaching-excellence awards from University of Montreal, a French-speaking Quebec institution that is strongly committed to research.

For ease of adjustment while it was being carried out and during the gradual formulation of the very object of the investigation, I opted for a qualitative approach. I also highlight its ability to 
describe in detail several major aspects of social life related to culture and life experience given, rightly, its ability to enable the researcher to reflect on viewpoints from the inside (Pires, 1997). I selected the grounded-theory approach as our analytical method in order to empirically establish theories using the professors' own words. Let us recapitulate that the grounded-theory approach is established and validated in parallel with the constant-comparative method which is carried out between observed facts and emerging analysis (Glaser and Strauss,1967). Consequently, the theorisation ensures that the result is, as it should be, "firmly grounded in empirical data" (Paillé, 1994, p. 150). To optimise this iterative approach of the gradual theorisation of a phenomenon, I observed the six basic steps (codification, categorisation, communication, integration, establishing a model and theorisation) (Ibid.).

\section{Analysis and Results}

\subsection{Why Do Professors Innovate?}

In answer to our research question, the respondents actively participated through identifying and describing why they innovate. Extraction of the data enabled us to formulate our analysis around thirty-four (34) sub-topics connected to the main reasons which led the professors who were interviewed to pedagogical innovation. Once again, it is a question of substantive categories (Glaser \& Strauss, 1967) that use the words of the participants collected during the individual interviews, without modifying them. In that which follows, I shall provide an introduction to and an analysis of the data, taking care to alternate discursive proposals taken from interview segments, references to literature sources, and parts that are our own interpretation. It is a question here of the ordered reconstruction of the professors' words that is always consistent with our research questions.

In their interviews, professors express their desire to engage minds as a major reason for innovating. That is to say that they want to capture students' attention and to interest them in what they are teaching in class. I have extracted an extremely important fact from the data about the reasons for innovating which is being in tune with students. For the professors, it is a question of meeting the student at his or her pace of learning and tying in with their current life events in order to facilitate the transmission of knowledge. To keep student interest alive, nineteen professors also explain how they seek to involve students in their learning. They want to see them participate, be active, discuss, and lead them to self-responsibility with respect to their learning.

Subsequently, another reason for innovating that is mentioned by three respondents is to reach the most students. Indeed, professors explain that one of their pedagogical goals is to become interested in students who are experiencing some learning challenges and to be able to enrich their teaching with respect to all of the students. In their own words, pedagogical innovation allows them to reach the greatest number of students.

Finally, four professors raise the reason of knowledge accessibility as a means of decompartmentalising classes and making them more accessible in order to retain student interest outside of the classroom. Consequently the reason for innovating takes on another dimension here, offering students the freedom of being able to study when they have the 
chance to and whatever their geographical location.

Extraction of the data from interviews with six of the respondents brings up a crucial element regarding the role of the professor: some participants state that they see it as natural coaching of the student as much from the perspective of his or her future profession and the subject itself, as research, their learning, or the personal support of the student. Supporting the profession entails preparing students for their future roles and ensuring that they become skilled at performing the duties that they will be required to carry out.

In the same way, ten of the respondents expressed as a reason for innovating, the desire to guide their students through the subject in order to lead them to a new and different understanding. At the same time, ten professors want to facilitate appropriating content and integrating the subject.

Seemingly, although it seems quite obvious that doctoral students should be supported in discovering how to conduct research and in their research career, the fact of integrating this from undergraduate level constitutes one of the reasons which encourages five of the interviewed professors to innovate. They consequently want them to experience research as soon as possible.

With a similar perspective, fifteen professors maintain that they innovate for the purposes of guiding students towards their future career. They believe that their role goes beyond the acquisition of knowledge and that they must help students to develop skills that they can use in their future work.

Additionally, for six participants, a reason for innovating arises from a relatively straightforward intention. Initially, they want the students to learn, want to equip them, and seek in-depth learning for their students. Consequently, six respondents underscored the importance of their intention of guiding students through learning.

Finally, four professors explain that one of the reasons which encourages them to innovate is the desire to support students through life's tribulations. It is a question, for example, of starting from students' prior knowledge and life experience and assisting them throughout their university careers, supporting them during the good times and the bad. For twelve respondents, one of the reasons for innovating is inspired by the goal of finding solutions to address the problems that they encounter or to meet their needs.

Participants raised nine (9) distinct problems that they deem to be reasons for innovating and that they shared in detail. Firstly, for nine of the interviewed professors, it is a case of students retaining information. Indeed, some participants explained that they have noticed that students do not remember anything they learned several years before or even during the previous year. Secondly, four professors highlighted that dissatisfaction with the world of work might drive pedagogical innovation. They share that some criticism and observations sufficed to motivate them to set up, amend, or even rebuild their entire programme and change their pedagogical approach to satisfy the working environment. They voluntarily chose to link things to the outside world. 
To a lesser extent, other issues driving professors to innovate are recurring ones and involve large student groups for four of the respondents. The particularly long length of classes at the University of Montreal is evoked by three participants.

The heterogeneity of students' levels in classes is mentioned by one participant, as is encouraging students to complete their studies with a degree. Two professors want to counter inertia through innovating within a very formal institution which is slowing down some changes that are eagerly expected because of its size.

Two participants express their desire to increase student class attendance and dissatisfaction with student learning in general and specifically with learning by heart without understanding content.

In parallel, eighteen professors give, as a reason for innovating, their intention to improve student learning and to assess them for the purpose of perfecting their understanding. It is primarily a question of finding new ways in which to offer learning strategies for the acquisition of knowledge and the development of new skills and then to test them, with the main aim of increasing and improving student learning. Furthermore, five professors mention, as a reason for innovating, their desire to improve student learning by means of assessing their students' learning. In addition, it would appear that, according to three respondents, improving students' understanding means detecting student difficulties so that the message to be conveyed can be adapted in order that students understand it even better.

Thirteen professors state that it is their own motivation that drives them to innovate. In other terms, they explain this in the sense that they do not want to get bored and become trapped in routine practices that would, in their opinion, have a negative impact on the quality of their teaching. Their motivation to teach must remain intact.

Of less importance, yet nonetheless a factor, four professors provide, as a reason for innovating, dissatisfaction with their own teaching, which motivates them to review their methods in a particularly critical way. Finally, a participant feels obliged to follow new information and communications technologies (NICTs), which are imposed, on them.

According to eight interviewed teachers, one of the reasons for innovating undeniably includes a need to have a closer relationship between them and the students. It is a question of accessibility that extends to the pedagogical relationship. Along the same lines, pedagogical innovation can be used for operationalising a change in the student- professor relationship according to the participants. Directly linked to this, six respondents also point out the specific desire to opt for and establish interaction between students as a reason for innovating. Some professors explain that they want their students to be able to help each other with their learning. More generally, interactions between students during the class are also mentioned in the professors' interviews. It would appear that the teacher, still with the aim of stimulating students to become involved in their learning, wants to use pedagogical innovation in order to promote interaction within the classroom.

All things considered, two respondents cited the sharing of knowledge, the regrouping of university teachers within a school, and even the comfort of students, as reasons for 
innovating. In fact, specific situations can result in student stress. Three participants believe that they must innovate in order to safeguard student well-being which should ensure good progress is made in their academic studies.

The penultimate reason that is mentioned by one of the professors entails improving the way in which connections between certain concepts is presented to students. In this situation, the teacher wants to teach them to map out links between concepts, as an example. In conclusion, the last reason that encourages a professor to innovate is to produce a non-existent frame of reference, a work in French or a teaching manual specific to Quebec.

\subsection{Reasons to Innovate Motivated by Action Plans}

The presentation and analysis of the sub-topics on the reasons that lead professors to innovate allow seven recurring topics to emerge from participants' interviews. These are captivating students, support, problem solving, improving, re-adaptation, communication and creation. This invites us to establish the links and a ranking between the substantive categories corresponding to Paillé's (1994) crucial connecting stage. I can establish relationships between the categories. I analyse internal and transverse recurrence and their degree of congruity with the "theoretical project"(Fourez, 1988) of our research, which aims to shed new light on the reasons for which professors innovate. Through our study, the construction of formal categories operates through the connections which have emerged between substantive categories, and their ranking in view of our project. This is part of a process of comparative and continual analysis of data, a kind of continuous passing back and forth between the substantive categories taken directly from participants' interviews and those established by the researcher. I suggest regrouping each of the sub-topics into one of seven (7) formal categories emerging from the presentation and the analysis of the data. I purposely name them action plans. They are represented visually in the Figure 1.

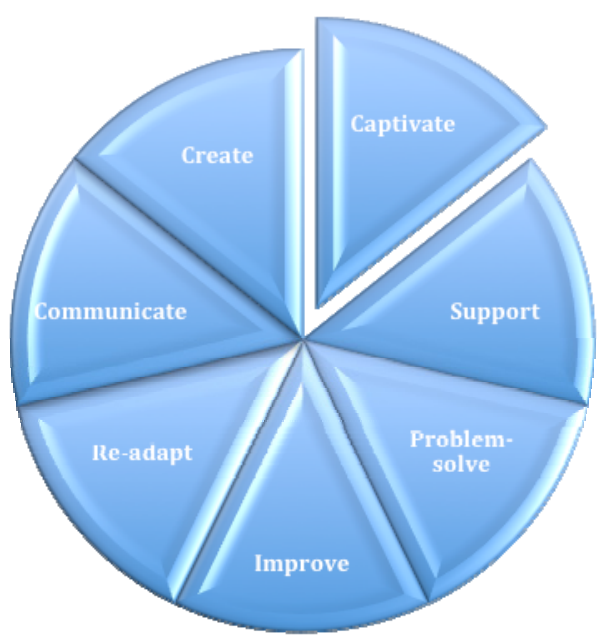

Figure 1. The reasons to innovate reprensented by seven action plans

In fact, each one of them represents a specific action plan. All of the actions that I have identified share one feature: intentionality. In other words, the plan to carries out a purposeful 
action for a specific reason and with a precise goal. The professors' interviews revealed the following categorisation when analysed: 1) Captivating, 2) Supporting, 3) Problem-solving, 4) Improving, 5) Re-adapting, 6) Communicating and 7) Creating. In other words, professors have, in their own words, the intention of captivating and supporting their students when they innovate. They want to resolve certain problems and improve learning. The professors want to re-adapt their teaching and communicate better with their students. Finally, they want to create. In order to assist the reader, I shall illustrate in the following table the seven (7) separate notions together with their sub-topics by frequency and situation.

Table 1. Pedagogical innovation action plans by frequency and case

\begin{tabular}{|c|c|c|c|c|}
\hline \multicolumn{2}{|c|}{ Action plans } & \multirow{2}{*}{$\begin{array}{l}\text { Sub-topics } \\
\text { Interest students }\end{array}$} & \multirow{2}{*}{$\begin{array}{l}\text { Frequency }{ }^{1} \\
54\end{array}$} & \multirow{2}{*}{$\begin{array}{l}\text { Cases }^{2} \\
19\end{array}$} \\
\hline \multirow{5}{*}{1} & \multirow{5}{*}{ Captivate } & & & \\
\hline & & Student involvement in their learning & 9 & 5 \\
\hline & & Being in tune with students & 11 & 6 \\
\hline & & Reach the most & 8 & 3 \\
\hline & & Accessibility & 6 & 4 \\
\hline & & Captivate & 88 & 37 \\
\hline \multirow[t]{6}{*}{2} & \multirow{5}{*}{ Support } & Learning & 11 & 6 \\
\hline & & The student & 10 & 4 \\
\hline & & The profession & 27 & 15 \\
\hline & & Research & 16 & 5 \\
\hline & & Subject & 23 & 10 \\
\hline & & Support & 87 & 40 \\
\hline \multirow[t]{11}{*}{3} & \multirow{11}{*}{ Problem-solve } & Problem-Need & 40 & 12 \\
\hline & & Completion of studies & 3 & 1 \\
\hline & & Heterogeneity of classes & 4 & 1 \\
\hline & & Overcoming inertia & 3 & 2 \\
\hline & & Classes last three hours & 4 & 3 \\
\hline & & To increase class attendance & 3 & 2 \\
\hline & & Retaining information & 12 & 9 \\
\hline & & Large groups & 4 & 4 \\
\hline & & Dissatisfaction with student learning & 3 & 2 \\
\hline & & Dissatisfaction with the world of work & 7 & 4 \\
\hline & & Problem-solve & 83 & 40 \\
\hline \multirow[t]{4}{*}{4} & \multirow{4}{*}{ Improve } & To improve student understanding & 4 & 3 \\
\hline & & Learning & 35 & 18 \\
\hline & & To assess learning & 13 & 5 \\
\hline & & Improve & 52 & 26 \\
\hline
\end{tabular}

\footnotetext{
${ }^{1}$ Frequency is the number of segments coded in relation to the sub-topic.

${ }^{2}$ One case is an interviewed professor participating in the research. This column represents the number of cases who have one or more segments coded to them by sub-topic.
} 


\section{Macrothink}

International Research in Education

ISSN 2327-5499

2014, Vol. 2, No. 2

\begin{tabular}{|c|c|c|c|c|}
\hline \multirow[t]{3}{*}{5} & \multirow{3}{*}{ Re-adapt } & Dissatisfaction with professors' teaching & 6 & 4 \\
\hline & & Motivation for the professor & 27 & 13 \\
\hline & & To follow NICTs & 1 & 1 \\
\hline & & Re-adapt & 34 & 18 \\
\hline \multirow{6}{*}{6} & \multirow{5}{*}{ Communicate } & Professor-student relationship & 15 & 8 \\
\hline & & Greater interaction between students & 6 & 6 \\
\hline & & To exchange knowledge & 3 & 2 \\
\hline & & Student well-being & 3 & 3 \\
\hline & & Reconciling professors within their school & 2 & 1 \\
\hline & & Communicate & 29 & 19 \\
\hline \multirow{3}{*}{7} & \multirow{3}{*}{ Create } & Connections between things & 2 & 1 \\
\hline & & A non-existent frame of reference & 2 & 1 \\
\hline & & Create & 4 & 2 \\
\hline
\end{tabular}

The reasons that lead to pedagogical innovation fall into seven action plans; nevertheless, I observe that the respondents do not cite these with equivalent frequency. That is to say that the professors' interviews brought up some action plans more frequently than other ones. Manifestly and as shown in the figure below, captivating, supporting and problem-solving are most often cited by the participants and could underpin the reasons for which they are driven to innovate.

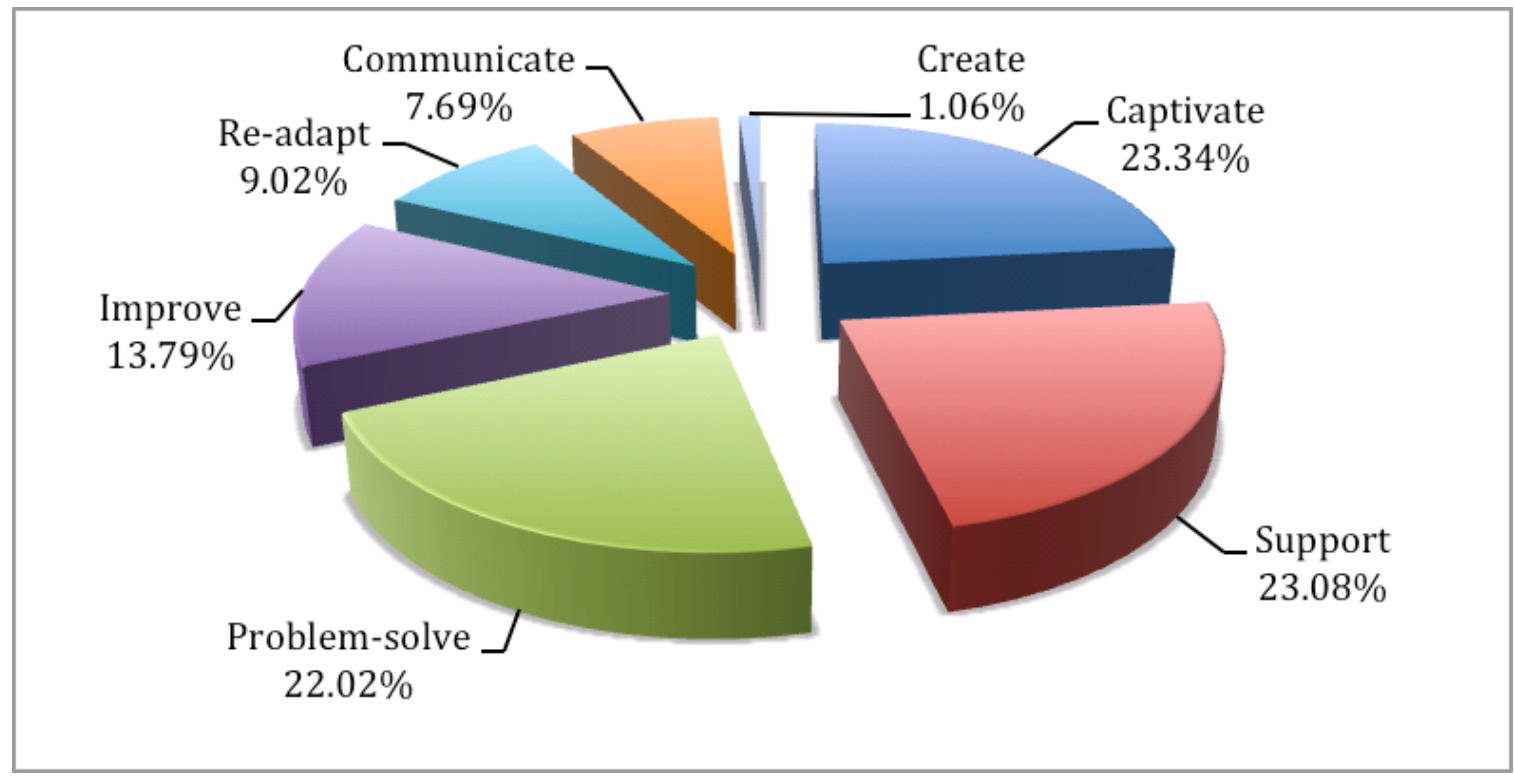

Figure 2. Representation of action plans as a percentage and by frequency

\subsubsection{Captivate}

The first action plan, captivating, mainly encompasses the notion of engaging the mind and, more specifically, capturing the attention of and interesting students during classes. A 
significant feature in the action of captivating is the fact of being in tune with students, that is to say going out of their way to evoke events in the life of the outside world to facilitate students' understanding. The participants also talk about seeking student involvement in their learning. Pedagogical innovation also allows them to reach the greatest number of students. Finally, the professors mention the reason of knowledge accessibility as a means of decompartmentalising classes and making them more accessible in order to retain student interest outside of the classroom.

\subsubsection{Support}

The second action plan, supporting, brings up a crucial feature regarding the role of the professor: some participants state that they see it as a natural coaching of the student as much from the perspective of his or her future profession and the subject itself, as research, their learning, or the personal support of the student. Supporting the profession consists of preparing students for their future roles and ensuring that they become skilled at performing the duties that they will be required to carry out. Similarly, respondents mentor students through the subject, either to guide them in understanding it or for the purpose of appropriating content. Seemingly, although it seems quite obvious that doctoral students should be supported in discovering how to conduct research and in their research career, the fact of integrating this from undergraduate level constitutes one of the reasons that encourage professors to innovate. Additionally, the respondents' intention appears to be relatively straightforward. They want students to learn, want to equip them, and seek in-depth learning. Finally, guiding students through life's tribulations also starts with the students themselves, ensuring they are supported throughout their university careers, during the good times and the bad.

\subsubsection{Problem-solve}

Through the third action plan, problem solving, professors innovate with the goal of finding solutions to address the problems that they encounter or to meet their needs. I have identified nine separate problems that the participants shared. In particular, it is a question of students retaining information from one year to the next. At the same time, dissatisfaction with the world of work has motivated them to set up, amend, or even rebuild their entire programme and change their pedagogical approach to satisfy the working environment. To a lesser extent, respondents nonetheless set out a recurring problem with respect to large student groups, the particularly long class periods at the University of Montreal (three hours), the heterogeneity of students' levels in classes, helping students to complete their studies by graduating, and countering inertia within a very formal institution which is slowing down some changes that are eagerly expected because of its size. No less present, the desire to improve student class attendance is a topic for which the interviewed professors want to implement solutions for the same reason as their dissatisfaction with student learning.

\subsubsection{Improve}

As the fourth action plan, improving, professors set out their intention to improve student learning and assess it for the purpose of perfecting their understanding. It is primarily a 
question of finding new ways in which to offer learning strategies for the acquisition of knowledge and the development of new skills, and then to test them, with the main aim of increasing and improving student learning. In addition, participants improve student learning by means of assessing their students' learning. To sum up, according to the respondents, improving students' understanding means detecting student difficulties so that the message to be conveyed can be adapted in order that students understand it even better.

\subsubsection{Re-adapt}

The fifth action plan, re-adapting, entails the self-motivation of professors which is tackled in the sense that they do not want to become bored and trapped in a routine. Of lesser importance, but still a feature that is present, participants raise dissatisfaction in their teaching, which drives them to question their methods and lastly the obligation to follow new information and communications technologies (NICTs) that are imposed on them.

\subsubsection{Communicate}

Communicating, the sixth action plan undeniably covers a need to have a closer relationship between professors and students. Directly linked to this, participants assert an specific desire to see interaction between students and, generally, more interaction between students in class is sought after. All things considered, some respondents cited the sharing of knowledge, the regrouping of university teachers within a school, and even student well being.

\subsubsection{Create}

The seventh and last action plan, creating, is concerned on the one hand with improving the way in which the existence of connections between certain things is presented to students, and, on the other, producing a frame of reference, a teaching manual which has not up until now existed in Quebec or in French.

\section{Discussion}

\subsection{Seeking Links between the Seven Action Plans}

I now propose an analysis which contextualises an underlying dynamic to participants' discourses. I am formulating a hypothesis, which suggests the existence of links and an order between the seven (7) action plans and I set this out visually in the following figure. 


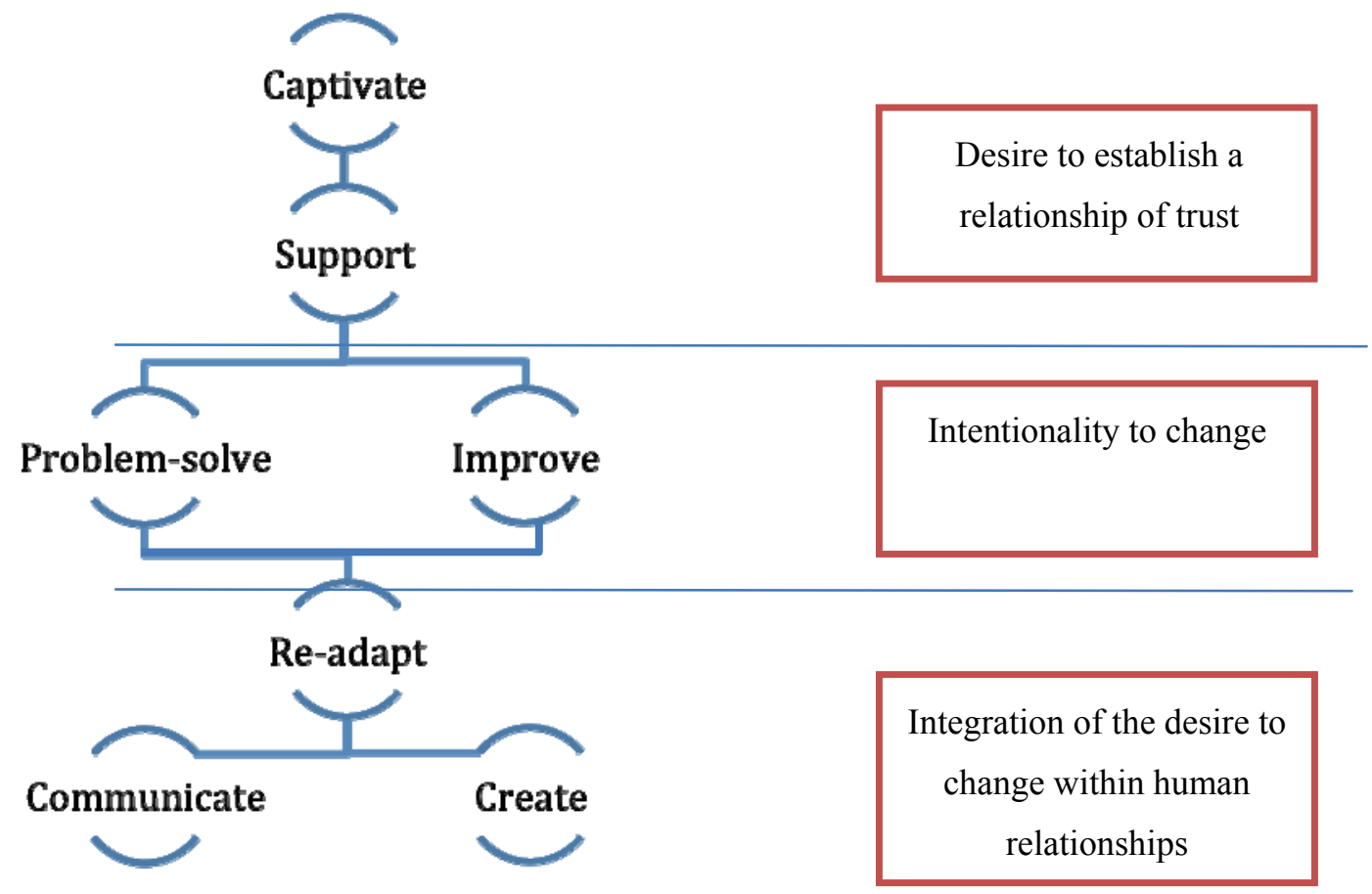

Figure 3. Links between the seven action plans

In fact, the categorisation of action plans for the main reasons that motivate the interviewed professors to innovate at the University of Montreal demonstrates three major phases. I explain these as firstly as a desire to establish a relationship of trust, secondly an intentionality to change, and thirdly, integration of the desire to change within human relationships.

The first phase, the desire to establish a relationship of trust matches the action plans of captivating and supporting students. The second phase, at the centre of the outline, evokes action plans supporting problem-solving or meeting needs and then improving learning, assessments, as well as student understanding as an intentionality to change. The third and final phase, the integration of the desire to change within human relationships, is comprised of two levels. The first concerns the professors in his or her desire to change what does not satisfy them in order to enable, during a second level, the desire to communicate by means of interaction and creation in order to obtain a better relationship of understanding.

\section{Conclusion}

Consequently, the primary reasons which motivate professors, in this university strongly committed to research, to develop pedagogically innovative projects may be categorised into seven action plans, 1) Captivating, 2) Supporting, 3) Problem-solving, 4) Improving, 5) Re-adapting, 6) Communicating and 7) Creating, and can be theorised in three major phases, 1). Desire to establish a relationship of trust, 2). Intentionality to change and 3). Integration of the desire to change within human relationships. In other words, it is a question of the desire to establish a relationship of trust with the intention of captivating and supporting students, an intentionality to change in order to provide a solution and improvement, and about the 
integration of the desire to change within human relationships, with the aim of re-adapting through communication and creation.

\section{References}

AUCC. (2003). La Recherche sans frontières. L'évolution du contexte de la recherche au Canada et des échanges avec les pays du Sud. Rapport final [Research without borders. The changing context of Canadian research and exchanges with Southern countries. final Report].

AUCC. (2006). Highlighting the impacts of North-South research collaboration among Canadian and southern higher education partners.

AUCC. (2007). Tendances dans le milieu universitaire, Volume 2 : Corps professoral [Trends in Higher Education, Volume 2: Faculty].

Baillargeon, N. (2011). Je ne suis pas une PME. Plaidoyer pour une université publique [ I'm not an SME. Advocacy for public university]. Collection Essai Libre. Montreal, Canada: Poètes de Brousse.

Barnett, R. (2003). Beyond All Reason: Living With Ideology in the University. Buckingham, UK: Society for Research in Higher Education and the Open University Press.

Béchard, J. P. (2000). Apprendre à enseigner au supérieur: l'exemple des innovateurs pédagogiques [Learning to teach in higher education: the example of pedagogical innovators]. Cahier de recherche OIPG $n^{\circ} 2000-001$, Septembre, 6.

Bertrand, D., \& Foucher, R. (2003). Les transformations du travail des professeurs des universités québécoises: tendances fondamentales et développements souhaités [The transformations of the work of professors of Quebec universities: key trends and developments desired]. Revue des éducations, 29(2), 353-374.

Bertrand, D., Busugutsala, G.G. \& Rhéaume, D. (1997). Nouvelles balises pour la réorganisationde la fonction enseignement de premier cycle dans les universités québécoises francophones [New tags for réorganisationde the undergraduate teaching function in francophone Quebec universities]. ERO-FEU, Rapport de recherche, Université du Québec à Montréal.

CFI (2013). Canada Foundation for Innovation. On http://www.innovation.ca /fr/AusujetdelaFCI/Historique.

Clark, B. R. (1997). The modern integration of research activities with teaching and learning. Journal of Higher Education, 68(3), 242-55. http://dx.doi.org/10.2307/2960040

Condorcet, N. (1994). Cinq mémoires sur l'instruction publique (1791) [Five memoirs Public Education (1791)]. Paris, France: Garnier-Flammarion.

Etzkowitz, H. (2001). The second academic revolution and the rise of entrepreneurial state. IEEE Technology and Society, 22(2), 18-29. http://dx.doi.org/10.1109/44.948843

Etzkowitz, H. (2003). Research Groups as quasi-Firms: the Invention of the Entrepreneurial 
University. Research Policy, 32, 109-121. http://dx.doi.org/10.1016/S0048-7333(02)00009-4

Fourez, G. (1988). La construction des sciences: Introduction à la philosophie et à l'éthique des sciences [The Construction of sciences: Introduction to philosophy and ethics of sciences]. Bruxelles, Belgium: De Bœck-Wesmaël.

Gingras, Y. (2003). Idées d'universités Enseignement, recherche et innovation [Universities'ideas Teaching, research and innovation]. Actes de la recherche en sciences sociales, 3(148), 3-7.

Glaser, B. G., \& Strauss, A. L. (1967). The Discovery of Grounded Theory. Strategy for Qualitative Research, Chicago, Aldine, 61-71, 67.

Hannan, A., \& Silver, H. (2000). Innovating in Higher Education: teaching, learning, and institutional culture. Buckgham, UK: Society for Research into Higher Education and the Open University Press.

Hannan, A., English, S., \& Silver, H. (1999). Why Innovate? Some Preliminary Findings from a Research Project on Innovations in Teaching and Learning in Higher Education. $\begin{array}{llll}\text { Studies in Higher 279-289. } & \text { Education, }\end{array}$ http://dx.doi.org/10.1080/03075079912331379895

Hattie, J., \& Marsh, W. (1996). The Relationship between Research and Teaching: A Meta-Analysis. Review of Educational Research, 66(4), 507-542. http://dx.doi.org/10.3102/00346543066004507

Henkel, M. (2004). Teaching and Research: the Idea of a Nexus. Higher Education Management and Policy, OECD, 16(2). http://dx.doi.org/10.1787/hemp-v16-art14-en

Jaspers, K. (1923). Die Idee der Universität. Berlin. Neufassung, 1946, Translated into English by H. A. T. Reiche and H. F. Vanderschmidt, The idea of the University, Boston, 1959. New edition with K. Rossman. Berlin, Göttingen, Heidelberg, 1961.

De Jonghe, A. M. (2005). Reorganising the Teaching-research Tension. Higher Education Management and Policy, OECD, 17(2).

Kogan, M. (2004). Teaching and Research: Some Framework Issues. Education Management and Policy, 16(2), 9-18.

Lessard, C., \& Tardif, M. (1998). La nature et la place d'une formation professionnelle selon les conceptions de l'université [The nature and place of vocational training in the conception of the university]. Paper presented as part of the REF-Toulouse.

Lindsay, R., Breen, R., \& Jenkins, A. (2002). Academic Research and Teaching Quality: theViews of Undergraduate and Postgraduate Students. Studies in Higher Education, 27(3), 309-27. http://dx.doi.org/10.1080/03075070220000699

Newman, J. H. (1889). The idea of a University. Part 1. University Teaching.

Paillé, P. (1994). «L'analyse par théorisation ancrée » [ «The grounded theory analysis »] 
Cahier de recherche sociologique, 23, 147-181.

Pires, A. (1997). Échantillonnage et recherche qualitative : essai théorique et méthodologique [Sampling and qualitative research: theoretical and methodological essay]. In Poupart, J., Deslauriers, J.-P., Groulx, L.-H., Laperrière, A., Mayer, R., Pires, A. La recherche qualitative. Enjeux épistémologiques et méthodologiques. Montreal: Gaëtan Morin, 113-167.

Press, E., \& Washburn, J. (2000). The kept University. The Atlantic Monthly, 285(3), 46.

Ramsden, P., \& Moses, I. (1992). Association between research and teaching in Australian higher education. Higher Education, 23, 273-295. http://dx.doi.org/10.1007/BF00145017

Smeby, J. C. (1998) Knowledge production and knowledge transmission. The interaction between research and teaching at universities. Teaching in Higher Education, 3(1), 5-20. http://dx.doi.org/10.1080/1356215980030101

Turk J. (2005). L'enseignement postsecondaire au Canada à la croisée des chemins [Post-secondary education in Canada at the Crossroads]. Sauvons la recherche, Dialogue national sur l'éducation supérieure, Ottawa.

Von Humboldt, W. $(1809,1810)$. On internal and external organisation of higher scientific institution in Berline (1809 to 1810). In Ferry, L., Pesron, J.-P. et Renaut, A. (1979). Philosophies de l'université, L'idéalisme allemand et la question de l'Université, Paris: Payot.

Whitehead, A. N. (1929). The aims of Education. New York, USA: Macmillan Co.

\section{Copyright Disclaimer}

Copyright reserved by the authors.

This article is an open-access article distributed under the terms and conditions of the Creative Commons Attribution license (http://creativecommons.org/licenses/by/3.0/). 